\title{
Revitalization of urban areas through business and tourism improvement districts (BIDs/TIDs) in Albania
}

\author{
Ermira Repaj \\ Department of Management, Faculty of Economy \\ University of Tirana, Albania
}

\section{Keywords}

Albania, business improvement district, economic development, public-private partnerships, tourism improvement district, urban regeneration.

\begin{abstract}
The spreading of business improvement districts (BIDs) and similar forms of a public-private partnership, as a new mechanism of urban revitalization and economic development, have emerged in Canada five decades ago and quickly adopted to many cities in countries such as the USA, Germany, UK, South Africa and lately Denmark and Sweden. This form of a public-private partnership with local authorities is created when a significant number of businesses or business property owners agree through a democratic process ballot to manage a delimited area and offer additional public services such as security, maintenance, infrastructure improvement, and marketing, to improve decaying commercial and residential areas.

Since 2011, the model has been applied in 8 districts in Albania, contributing to improved business life, infrastructure improvement, and enhanced general public services. The period is long enough to offer insights regarding their evolution and transformative effect in the areas where it has been applied.

This paper aims to explore the adaptation of the business improvement district (BID) model in urban areas in Albania and, at the same time, point out its characteristics, activities, and contribution to the area development.

The methodology used includes a qualitative research design, including primary and secondary data sources. Primary data sources include interviews with BID association members, administrators, and consultants in Albania, businesses, local government officials, and lawyers. Secondary sources include different research papers on BID functionality and BID legislation, conference proceedings, project reports, entrepreneurship magazines.

By identifying the effects of the model in area transformation, this study results have important implications for Albania's public and development policies and extracts practical lessons from its introduction in this local context. The findings presented demonstrate BID's transformative role for area renewal, economic and social development of the areas where it has been applied.
\end{abstract}

\section{Introduction}

The BID (Business Improvement District) and TID (Tourism Improvement District) are relatively new international models of public management, locally embedded through securing private capital to accommodate local specific demand related to area renewal, economic and social issues (Peyroux et al., 2012).

Historical records show that the first model of a Business Development Zone was implemented in Toronto in 1970 to fund a commercial district's renewal. In the following decades, the model has expanded to several cities in Canada and other countries such as the United States (Mitchell, 1999), South Africa (Didier et al., 2012), Germany (Michel and Stein, 2014), the United Kingdom (Cook, 2009) and lately Denmark (Richner and Olesen, 2018) and Sweden (Valli and Hammami, 2020) as a new mechanism of urban revitalization and social-economic development (Hoyt, 2003; Billings \& Leland, 2009). The model is almost the same, a flexible form of governance that allows its participants to autonomously operate and craft solutions to improve their lives in a single area, thus creating a more attractive destination offer for tourism, leisure, shopping, living, and doing business. Being entirely local, the model helps prioritize initiatives that directly affect the community. The merger of most businesses creates the opportunity to better cope with joint services such as sanitation, security, and collective marketing. 
The BID / TID model's long-term impact is creating sustainable mechanisms that improve the commercial value of the area by enhancing its assets and marketing to the general local public and visitors. Impact sustainability is ensured by actively involving the local community, businesses, and the Municipality as actors for improvement.

BIDs have been operating in Albania since 2011, as an initiative of the Albanian- American Development Foundation, and their immediate impact is directly reflected in the daily turnover of businesses, improved employment rates, the increase in the number of visitors, but also the increase in the value of properties and new business investments.

This paper focuses on applying this international model in the Albanian context and its transformative role for area renewal, economic and social development of the areas where it has been applied.

This article is divided into five sections. First, the introduction of the BID model definition and origin will be discussed through a literature review. Second, there will be an analysis of the implementation of the BID model across Albania. Third, the bespoke characteristics of the Albanian model will be detailed. Finally, some relevant BID projects' outcomes and impact indicators will be showcased before summarizing this article's conclusions.

\section{Introduction to BID concept - A literature review}

There is no universal definition for a business improvement district (Becker et al., 2011) because the very nature of a BID is to be adaptive and flexible to serve each district as needed by stakeholders (Hoyt, 2003). The model definition varies depending on the country or region where it has been implemented, its' regulations, or other local conditions.

Business Improvement District (BID) in the USA, Business Improvement Areas in Canada (BIA), Urban Improvement District (UID), Neighborhood/Housing Improvement District (NID \& HID) or Innovation areas in Germany, same concept with local variations that despite its different nominations are still recognizable (Eick, 2012; Stalevska \& Kusevski, 2018).

Business Improvement District (BID) is, in general, the most used terminology to denominate the model and its characteristics.

Despite its different nominations, there is some agreement in the literature on the model's general characteristics. The district can be a public-private partnership in a geographically defined commercial area, authorized by local and state governments with a mandatory fee structure, often called BID levy, and collected by local authorities. BIDs are established through a ballot of those who will be expected to pay the levy, business occupiers, or property owners. The district must perform traditional BID services such as capital improvements, additional cleaning, area security, and marketing (Hoyt, 2003; Becker et al., 2011) that do not intent to substitute public services but are supplementary.

Their emergency is generally connected to revitalizing decaying urban areas, increasing area footfall, improving the general conditions of the businesses operating in the area, and increasing their respective turnovers.

This neoliberal urban governance approach has been seen as a new trend in decentralization policy efforts and a shift in urban entrepreneurialism involving more urban governance actors (Ward, 2006; Peyroux et al., 2012; Stalewska \& Kusevski, 2018). The introduction and spread of the model are subject to conditions/factors such as the area/region's socio-economic context, including population size, entrepreneurial and commercial tradition (Eick, 2012; Costela-Sánchez, 2018). Other factors that influence the introduction of the model are the political context and the supportive legal framework, availability of governmental funding, and the commitment of different actors such as the public, the private, or third sectors that support the process. (Gopal-Agge and Hoyt 2007; The Means, 2013; Costela-Sánchez, 2018).

While there are evidence and a consensus in the international academic literature that the model has played an essential role in area revitalization through responding to local challenges more effectively, empowering and strategically advancing the business and retail (Levy, 2001; Gopal-Agge and Hoyt 2007), destination promotion and marketing, critics express concerns about potential spill-over effects.

Despite its recognized impact in the local context where it has been applied, the model has raised a few questions and critics regarding its effects on some issues such as democracy and proper representation in the managing boards, accountability, inequality in the delivery of public services or 
over-regulation on public spaces (Gopal-Agge and Hoyt 2007; Stalewska \& Kusevski, 2018). Other critics also raise the concern about the potential effects of exclusion and gentrification through moving social problems elsewhere rather than solving them (Valli and Hammami, 2020).

To date, there has been no academic study of the application of the BID model in Albania, which looks at all model aspects, its characteristics, impact, and potential implications. This article contributes to spreading knowledge on BIDs to fellow researchers, public authorities, business associations, and the general public through an in-depth case study research.

\section{Implementation in Albania}

The Albanian-American Development Foundation (AADF) has been instrumental in initiating and supporting first business improvement district (BIDs) initiatives in some Albanian urban and touristic areas.

AADF's BID/TID projects include two essential components. First, decaying urban areas undergo an infrastructural investment that provides a significant facelift to all buildings and public spaces. Central and local government entities collaborate during this phase, providing support and additional funding. The BID model's initial focus was on cities' central avenues with a later shift on areas with historical and cultural values, such as old bazaars and historic neighborhoods. The goal was to turn them into vital, thriving touristic destinations, hence the TID acronym.

The second component of the project develops local capacities to manage the area successfully in the long run. For that purpose, a local businesses' association is formed, and the respective Municipality agrees to transfer to the association the collected local tariffs from the area. An elected board, where representatives from the AADF and the Municipality also sit, is chosen to oversee activities and budget implementation. The BID association provides additional services to strengthen local businesses and make the area more attractive for new investments, such as business matching grants for investments, capacity building services for businesses, place marketing, and networking with similar local or international organizations.

Large scale capital investment in the public infrastructure that has taken place in these pilot BID/TID areas have typically preceded any efforts to establish BID organizations, missing the chance to use the promise of capital investment to raise interest and secure participation and engagement from the private sector at an early stage (The Means, 2015). However, the second component funds and local government transfer to the association have been seen as a strong incentive in later stages to increase the private sector's engagement in area management.

From June 2020, the trajectory of BIDs in Albania has taken an interesting turn toward the introduction and approval of the BID legislation that institutionalizes the BID/TID structure, regulating their creation and functionalities, also providing them with a long-term, sustainable funding mechanism.

According to the BID law, business improvement districts, as public-private partnerships, can be initiated by the business owners in a specified geographically commercial area through a BID prospect that should be voted positively through a ballot by $50 \%$ of the BID participants and finally approved by the local authority (Municipality). The BID has a limited mandate of 3 or 7 years, after which it should be re-voted by its members. The BID does not substitute the local government public services but has an enhancement role, providing additional services such as area security, infrastructure improvement, cleaning and maintenance, area marketing, and beautification. All the BID participants should pay a mandatory fee called BID levy, which was previously agreed in the BID prospect and is collected by local authorities. The managing board includes business representatives that make the majority for decisionmaking, also representatives from local government and other strategic development partners with an oversight role regarding program and budget implementation.

\section{Methodology}

The methodology used includes a qualitative research design, including primary and secondary data sources. Primary data sources include in-depth interviews with BID association members, BID administrators, and consultants in eight business improvement districts in Albania, business owners, local government officials, and lawyers. Secondary sources include a review of existing international literature 
on BID functionality and BID legislation, articles, and conference proceedings, BID project reports, planning documents, entrepreneurship magazines, and BID websites.

Empirical material regarding the BID formation process, BID members, organizational form, geographical boundaries, and business structure has been obtained through BID reports, AADF project reports, BID websites, and municipalities. A more in-depth understanding of the context and the impact in different aspects have been obtained through semi-structured interviews with varying BID actors.

\section{Findings}

The business improvement districts founded in Albania since 2011 have emerged in a similar socialeconomical context, with slight urban differences. The initial focus of the BID model was on cities' central commercial avenues like BID Shkodra, BID Korça, and BID Berat with a later shift on areas with historical and cultural values, such as old bazaars (TID Kruja, TID Tirana, TID Korça, TID Gjirokastra) and historic neighborhoods (TID Vlora). Most of these areas were facing similar economic-social problems, like decaying public infrastructure, substandard public services, weak destination marketing but high economic potential. While locals and visitors naturally visited the city centres and old bazaar commercial areas, TID Korça (Korça Bazaar) and TID Vlora (historic neighbourhood) were marked as vulnerable areas with a low footfall, abandoned and decaying housing and business premises, also with some security issues.

Data from AADF evaluation reports show the following BID/TID model impact indicators for eight areas and more than 900 businesses:

- On average, there is an increase of over $110 \%$ of visitors in all revitalized areas.

- Data from reports show a 70\% increase in commercial property value reflected in higher property prices and rents for square meters.

- Local businesses report a 75\% increase in business earnings after AADF's intervention

and management model.

- An increased business satisfaction towards public service by $130 \%$.

- For every $\$ 1$ committed by AADF, businesses have joined the area improvement initiative by upgrading their businesses by $\$ 2$.

One of the evident contributions of the applied model in Albania is the opportunity of building partnerships and lobbying with the relevant authorities to enable the provision of qualitative public services according to the needs and challenges of the businesses in the area, in a sustainable way, but also empowering the business owners' community and providing them with an instrument to contribute to area management.

The preparation and implementation of qualitative management plans for the BID/TID that designs the whole process of development and management of the area, including the orientation of the mix of services in the district; marketing and branding elements; BID/TID management structure, clarified the organization's position, improved its efficiency, and helped to discipline BID stakeholders' behaviour.

The intervention for infrastructural improvement and the area's promotion locally and internationally contributed to the overall area frequentation and footfall. Today BID/TID areas are the most frequented areas by tourists in the respective cities. Infrastructural improvement of public spaces and facades; improved business premises and services through the grant program and business capacity building programs; sanitation and safety of the area; and other beautification elements added value and improved the life not only of residents but also of visitors and tourists.

BID organizations contributed to the overall improvement of business turnover, quality of services, and business sustainability. In TID Kruja, the artisans have been supported with specialized consultancy services to improve their entrepreneurial skills, product designs, and marketing and produce more than 300 new product prototypes and techniques. Businesses in BID Shkodra, TID Kruja, TID Korça, BID Berat, TID Gjirokastra have been supported with interior design projects to improve their premises, and business offer also reflected in a higher number of visitors and higher turnover.

Destination marketing is another powerful instrument used by the BID/TID associations to increase the area's attractiveness. A distinctive brand, which identifies the BID area, with details ranging from the logo and colors used, the symbols, the banners, media communication, the signage boards, the businesses 
accessories (such as uniforms, boards, cups), all elements that also create a sense of belonging and collaboration. Events organized in these areas served as a magnet for attracting visitors and tourists, complementing, and improving the area's touristic offer and social and cultural life. Statistics from project reports display an increase of $70-150 \%$ in the footfall due to promotional events organized in the BID/TID areas.

While there is enough evidence on the positive outcomes of the BID model, some internal issues have been reported by BID administrators and consultants, such as lack of involvement by residents and the wider public, weak membership or engagement in the case of TID Kruja and BID Berat and delays on municipality transfers for the association that creates financial instability for the model. While the first and second issues have been addressed through a more active role of the managing structure with public and members engagement, the financial sustainability issue is being addressed through the new legislation on the BID model that regulates its funding mechanism. BID organizations are also testing other instruments to secure economic sustainability by offering paid services such as a skating rink and a scenic train trip in BID Korça, but there is no evidence of their success yet.

\section{Discussion \& Conclusion}

Despite the discussions and concerns between scholars, there is evidence and a consensus in the international academic literature that the BID model has played an essential role in area revitalization through responding to local challenges more effectively, empowering and strategically advancing the business and retail (Levy, 2001; Gopal-Agge and Hoyt, 2007), destination promotion and marketing, converting them in vibrant commercial centers.

Despite its recognized impact in improved public services and better response to local challenges, the success of the BIDs in providing such services is essentially seen by some scholars as to the failure of the local municipal government (Briffault, 1999). While BIDs are seen as contributors to additional public services, they cannot be considered the primary service provider or a substitute for the local government. BIDs should be regarded as an essential instrument of collaboration on mutual issues, creating ties between the local community and local government.

While BID members and stakeholders notice improved area attractiveness, better business climate, higher estate values, improved public services, and sense of security, this improvement is based on collective action, higher engagement of private sector in area management, eradication of the free riders, provision of additional private funding for public improvement, disciplining of BID members behavior and policy partnerships with local government.

Few elements remain critical for this model's success: An active engagement of the private sector and local government in communal decision making for area management would be essential for BID model functionality. A business-critical mass that would ensure the model's economic sustainability in terms of levies collected is a second key success element. A healthy financial situation of the BID organization would also guarantee the right instruments and mix of services to create a significant impact in the BID area.

By identifying the effects of the model in area transformation, this study results have important managerial implications for Albania's public and development policies and extracts practical lessons from its introduction in this local context. The findings presented demonstrate BID's transformative role for area renewal, economic and social development of the areas where it has been applied.

\section{Limitations and further research}

The limitations of this research stem from the inability of this study to identify BID entities not initiated or not related to AADF.

In future research, a quantitative approach can be employed in the research topic to identify the impact of the model on different stakeholders, including property owners that were not part of this study.

A more in-depth investigation should be done into the transformation process for existing BID organizations to fit the recently approved BID legislation. Furthermore, the new BID entities' emergency under the BID law should be investigated.

Moreover, further research is required to provide solutions for BID organizations to maintain sustainability and generate more impact. 


\section{References}

Becker, C., Grossman, S., \& Dos Santos, B. (2011). Business improvement districts: census and national survey. Washington, D.C., International Downtown Association.

Billings, S., and Leland, S. (2009). Examining the Logic Behind the Self-Help, Self-Taxing Movement: Business Improvement District Formation. Public Budgeting \& Finance, 29(4), pp. 108-124.

Briffault, R. (1999). A Government for Our Time? Business Improvement Districts and Urban Governance. Columbia Law Review, 99(2), pp.365-477.

Cook, I. (2009). Private sector involvement in urban governance: The case of Business Improvement Districts and Town Centre Management partnerships in England. Geoforum, 40(5), pp.930-940.

Costela-Sánchez, Á. (2018). German Business Improvement Districts (BIDs) as a model for Spain. GIGAPP Estudios Working Papers, No. 80. pp. 33-48

Didier, S., Morange, M. and Peyroux, E. (2012). The Adaptative Nature of Neoliberalism at the Local Scale: Fifteen Years of City Improvement Districts in Cape Town and Johannesburg. Antipode, 45(1), pp.121-139.

Eick, V. (2012). The co-production of purified space: hybrid policing in German Business Improvement Districts. European Urban and Regional Studies, 19(2), pp.121-136.

Hoyt, L (2003). The Business Improvement District: An Internationally Diffused Approach to Revitalization. [Online] Available https://www.researchgate.net/publication/237569027_The_Business_Improvement_District_An_Internationa 1ly_Diffused_Approach_to_Revitalization [Accessed August 15, 2020].

Hoyt, L. and Gopal-Agge, D. (2007). The Business Improvement District model: a balanced review of contemporary debates. Geography Compass 1(4), pp.946-958.

Levy, P. (2001). Paying for public life. Economic Development Quarterly 15 (2), pp.124-131.

Means, T. (2013). Review of Business Improvement Districts in Wales. [On-Line] Available at: https://www.themeans.co.uk/sites/default/files/bidsreview_0.pdf [Accessed 18 October 2020].

Michel, B. and Stein, C. (2014). Reclaiming the European City and Lobbying for Privilege: Business Improvement Districts in Germany. Urban Affairs Review, 51(1), pp.74-98.

Mitchell, J. (1999). Business improvement districts and innovative service delivery. New York: The PricewaterhouseCoopers Endowment for the Business of Government.

Peyroux, E., Pütz, R. and Glasze, G. (2012). Business Improvement Districts (BIDs): the internationalization and contextualization of a 'travelling concept'. European Urban and Regional Studies, 19(2), pp.111-120.

Richner, M. and Olesen, K. (2018). Towards business improvement districts in Denmark: Translating a neoliberal urban intervention model into the Nordic context. European Urban and Regional Studies, 26(2), pp.158-170.

Stalevska, M, Kusevski, D. (2018). Business Improvement Districts and their role in the Swedish context. In: Baeten, G, Björk, F, Edvik, A, Parker, P (eds) Reports from Urban Studies Research Internships 2017. Malmö: Malmö University, pp. 14-51.

Valli, C. and Hammami, F. (2020). Introducing Business Improvement Districts (BIDs) in Sweden: A social justice appraisal. European Urban and Regional Studies, p.096977642092552.

Ward, K. (2006). 'Policies in Motion', Urban Management and State Restructuring: The Trans-Local Expansion of Business Improvement Districts. International Journal of Urban and Regional Research, 30(1), pp.54-75. 